\title{
Voters' commitment problem and reforms in welfare programs
}

\author{
David Hollanders • Barbara Vis
}

Received: 28 November 2009 / Accepted: 5 August 2011 / Published online: 15 September 2011

(C) The Author(s) 2011. This article is published with open access at Springerlink.com

\begin{abstract}
When will a vote-seeking government pursue unpopular welfare reforms that are likely to cost it votes? Using a game-theoretical model, we show that a government enacts reforms that are unpopular with the median voter during bad economic times, but not during good ones. The key reason is that voters cannot commit to re-elect a government that does not reform during bad times. This voters' commitment problem stems from economic voting, i.e., voters' tendency to punish the government for a poorly performing economy. The voter commitment problem provides an explanation for the empirical puzzle that governments sometimes enact reforms that voters oppose.
\end{abstract}

Keywords Commitment · Political economy $\cdot$ Reform $\cdot$ Welfare-programs

JEL Classification D72 $\cdot \mathrm{D} 78 \cdot \mathrm{H} 11 \cdot \mathrm{H} 5 \cdot \mathrm{I} 38 \cdot \mathrm{J} 48$

\section{Introduction}

Public opinion research shows that the cards are very much stacked in favor of the welfare state status quo. A majority of voters, including the median voter holding the median policy preference, value core welfare programs such as public pensions and unemployment benefits and prefer to uphold the status quo rather than cutting back these programs (Boeri et al. 2002; Blekesaune and Quadagno 2003; Brooks and Manza 2007; Van Groezen et al. 2009).

Electronic supplementary material The online version of this article

(doi:10.1007/s11127-011-9872-1) contains supplementary material, which is available to authorized users.

D. Hollanders

TiasNimbas Business School, Tilburg University, P.O. Box 90153, 5000 LE, Tilburg, The Netherlands

B. Vis $(\bowtie)$

Department of Political Science, VU University Amsterdam, de Boelelaan 1081, 1081 HV Amsterdam, The Netherlands

e-mail: b.vis@vu.nl 
Consequently, vote-seeking political parties have the best chance of attaining their voteseeking goal when they refrain from reforming these programs in the direction that the median voter dislikes. This political obstacle to reform is one of the central explanations for why welfare states remain remarkably stable despite mounting pressures for change, like ageing populations and globalization (e.g., Pierson 2001; Brooks and Manza 2007). Notwithstanding the serious political obstacles to reform, many governments in advanced democracies have pursued reforms that are unpopular, such as increasing the pension age or cutting back benefits. Recent examples of reforms that do not benefit the median voter include the reduction of the level of public pensions and/or wages of civil servants in Ireland, Greece and the Netherlands.

When do governments pursue unpopular reforms? When are they willing to accept the electoral risk involved? These questions have arrived at the forefront of the comparative literature on the welfare state (see e.g., Starke 2006; Vis 2010), but are not answered satisfactorily yet. Most studies simply assume that when governments get the chance to reform, for instance because the institutions allow it, they will do so. When reforms are unpopular with most voters, the government will turn to so-called blame avoidance strategies to try to shift responsibility for the reform (e.g., Weaver 1986; Vis and Van Kersbergen 2007). One possible blame avoidance strategy is to find a scapegoat, like the European Union (EU). Another is to gather the support of opposition parties for the reform, leaving voters with nowhere else to turn. While providing useful insights into how unpopular reforms can be implemented, this literature leaves unexplained why some governments enact unpopular reforms and turn to blame avoidance strategies, while other governments do not enact these reforms at all.

We contribute to this scholarly debate by proposing a mechanism that simultaneously explains the occurrence and timing of welfare program reforms that are unpopular with the median voter. ${ }^{1}$ While there exists much political-economic literature on the commitment problem faced by politicians, the mechanism we propose is based on a commitment problem faced by voters. We present a simple game-theoretical model that formalizes how economic voting leaves voters unable to commit to re-elect a government that will not reform during times of economic hardship. If voters vote economically, they-correctly or not-at least partly blame their government for weak economic performance (Tufte 1978; Hibbs 1979; Lewis-Beck and Paldam 2000; Van der Brug et al. 2007). The voters' commitment problem means that a vote-seeking government will consider reforms only when it will likely be voted out of office anyway because of economic hardship. The central empirical implication of our model is therefore that unpopular reforms will generally take place during economic downturns. This implication is consistent with the work of, for instance, Høj et al. (2006). Focusing on 21 OECD-countries between 1975 and 2003, Høj and colleagues find that economic crises, operationalized as output gaps larger than four per cent, are associated with more reform in both the labor market and the product market (see also Pitlik and Wirth 2003; Vis 2010).

The article's structure is as follows. We first discuss the comparative welfare state and political-economic literature on welfare program reforms and argue that this literature does

\footnotetext{
${ }^{1}$ Our model applies to those reforms that negatively affect the median voter. In the current context of "permanent austerity' (Pierson 2001), most reforms are either of this type or what Vis (2010) labels 'not-unpopular reforms'. The latter are reforms that the median voter does not dismiss, but which are also not popular in that they positively affect her voting decision (like active labor market policies). Welfare reforms that are popular in that they positively affect the median voter are rare, if not absent, nowadays. For instance, the adoption of family policies in many developed democracies over the past years does not get the support of the median voter, who is too old to benefit directly and does not behave socio-tropically on this issue.
} 
not adequately account for the occurrence, and especially the timing, of reforms that are unpopular with the median voter. We then introduce the game-theoretical model, and analyze a special case that provides some intuition on the mechanism at work. We subsequently analyze the general model, which we finally extend to allow for the possibility that reform positively influences future economic conditions. We end with some concluding remarks.

\section{Related literature}

When do unpopular welfare program reforms occur, i.e., reforms that the median voter dislikes? That is to say, what is their timing? The answers put forward in the comparative welfare state literature and the political-economic literature on reform do not fully explain reforms' timing, as we show below.

\subsection{Comparative welfare state research}

A first body of comparative literature on unpopular welfare programs' reforms argues that the main cause for pressure on the welfare state-and thereby for reform-is socioeconomic change and the ensuing rise in the number of eligible recipients (Garrett and Mitchell 2001; Huber and Stephens 2001; Pierson 2001; Iversen 2005). This argument makes sense theoretically. For example, if population ageing is projected to lead to budgetary problems, the government may take measures to deal with the issue. However, the socio-economic account provides little theoretical footing as regards when exactly such measures are taken. When do governments pursue cutbacks that may be necessary, but which are also electorally risky? Why do some 'objective' problems lead to reform yet others do not?

A second perspective on welfare programs' reform focuses on political struggles, sometimes integrating socio-economic variables too. The argument is that the variation in the degree and type of reform is influenced by the partisan complexion of the government (e.g., Korpi and Palme 2003; Allan and Scruggs 2004) or by the dynamics of party competition (e.g., Kitschelt 2001; Green-Pedersen 2002). While offering useful insights into some of the factors that hinder or facilitate reform, this account cannot explain when governments engage in electorally risky activities. Why, for example, have unpopular measures been taken by some right-wing and by some left-wing governments in Germany, Denmark, and the Netherlands, but not by others (see Vis 2009)?

A third body of comparative literature on unpopular welfare reform focuses on the influence of institutions. The usual argument is that reform occurs most often in countries with fewer institutional hurdles and, therefore, highly concentrated political power. Reform consequently should be more likely in Westminster countries (such as the United Kingdom) than in political systems where governmental power is fragmented (like Switzerland and the United States). Several empirical studies support this hypothesis (e.g., Bonoli 2001). However, some authors note that the reverse relationship is also plausible (see Ross 1997). Political systems concentrating political power also concentrate political accountability. Consequently, '(...) voters know very well who they may blame for unpopular cutbacks' (Starke 2006: 109). In political systems where power is fragmented, conversely, avoiding blame for unpopular measures is easier (Weaver 1986; Pierson 2001), possibly causing more cutbacks. The institutionalist approach has been helpful in explaining the cross-national variation in welfare reform. However, it cannot explain the when of reform because governments in the same country face the same institutional constraints and opportunities (Armingeon et al. 2010), yet display various degrees of reform. 
A final strand of literature proposes that ideas matter for welfare programs' retrenchment. The argument here is that by invoking a specific discourse or imperative, governments may overcome the barriers to unpopular reform and implement it successfully (Cox 2001; Schmidt 2002; see Campbell 2002; Lieberman 2002). Studies focusing on the importance of ideas have added to the knowledge of the process of unpopular welfare reform. However, this literature offers little theoretical foothold on when ideas matter (see Lieberman 2002).

\subsection{Public choice literature on the welfare state}

Next we discuss the political economy of the welfare state. Congleton et al. (2011) give a recent overview of this literature. They discuss political-economic explanations for the expansion of the welfare state in the twentieth century, when government expenditure as a fraction of GDP rose sharply in most OECD countries. Congleton and colleagues distinguish two political-economic explanations for this growth. The first strand of literature emphasizes the role of preferences of voters and the political institutions that map these into policy outcomes. A second approach stresses the importance of interest groups and lobbying.

An influential and seminal contribution in the first field is Browning (1975), who uses a median voter model in the context of overlapping generations. Browning shows why a democracy may overspend on social security. When the median voter is middle-aged, she will regard past contributions as sunk while all benefits still lie ahead. When voting on social security, the middle-aged median voter thus considers all benefits but not all costs, resulting in an inefficiently high level of pension expenditure. Other papers have extended this argument (e.g., Tabellini 2000) or added nuance to it (e.g., Sjoblom 1985, see Galasso and Profeta 2002 for an overview of the political economy of social security). Meltzer and Richard (1981), for example, apply the median voter model to taxation, with the result that redistributive taxes are higher when the distance between the median and the mean income is larger. Other important theoretical political-economic work includes Barro (1979), Besley and Coate (1997), and Congleton and Bose (2010), who find that ideology is an important explanation for the size of the welfare state, and Persson and Tabellini (2000), who propose that presidential regimes spend less on welfare than parliamentary ones. Empirical contributions on the determinants of social security include Breyer and Craig (1997), Tepe and Vanhuysse (2009), and Mulligan et al. (2002).

The second stream of literature highlights the role of interest groups and lobbying. Important seminal contributions in this field include Becker (1983), Olson (1965), and Grossman and Helpman (1996). These scholars emphasize that the benefits and costs of social welfare programs are distributed unevenly and asymmetrically, so a minority may gain from a particular program while the losses associated with paying for it are spread over the majority. Contributors therefore do not face high losses individually, while beneficiaries have strong incentives to lobby for welfare programs. When doing so, they need to overcome the free-rider-problem by mobilizing own group members and coordinating their (voting) behavior. A related and influential model of Niskanen (1971) postulates that lobbying may also come 'from the inside', with civil servants pushing for higher budgets, as that increases their reputation and job opportunities.

The two approaches can be distinguished analytically but are hard to disentangle empirically. Still, Congleton and Shughart (1990) test the explanatory power of both approaches for the development of the welfare state. Their main outcome is that electoral demand (of the median voter) explains the development of social security in the United States better than political push (of special interest groups) does.

This large and established literature focuses mainly on explaining the existence and/or expansion of the welfare state. We contribute to this literature by considering if, how, and 
when welfare state programs are rolled back. With an ever older population, median voter models, for example, have difficulty explaining why (and if so, when) retirement benefits are lowered. The model we present is a game-theoretical one in the spirit of Acemoglu (2003). Where Acemoglu focuses on the commitment problem of politicians, we instead focus on a commitment problem of voters. As we elaborate below, the latter commitment problem provides a natural explanation of the existence and timing of welfare program reforms.

\section{A new mechanism: voters' commitment problem}

We propose a new mechanism, labeled voters' commitment problem, to account for the timing of unpopular reforms of welfare programs in democratic systems. The thrust of the argument is that, due to economic voting, voters cannot commit to re-elect a government that refrains from reform when the economy is in a poor state. Owing to this commitment problem, reforms of welfare programs take place during economic downturns only. ${ }^{2}$ Elections come with a pre-election commitment problem on the part of politicians, since they cannot commit themselves to implement the policies they support on the campaign trail. When in office, they may use their power to renege on their pre-election promises to voters. The crucial aspects of elections, the ability to 'throw the rascals' out at the next election, partly solves this commitment problem.

There is a similar commitment problem between elections on the side of the voters. This problem results from economic voting. Voters generally oust a government during an economic recession because they blame politicians, at least partly, for the economy's poor performance. There is a widespread consensus that economic voting is 'a generalized phenomenon in industrial democracies' (Pacek and Radcliff 1995: 44; see Van der Brug et al. 2007). Moreover, Easaw (2010) shows that news (good or bad) about unemployment shapes voters' perceptions (positive or negative) of a government's macroeconomic competence. Due to the omnipresence of economic voting, the pledge of the median voter before the election to re-elect the government if it refrains from an unpopular reform is therefore not believable and certainly not enforceable. Consequently, a vote-seeking government might reform during a recession because this reform will hardly influence its reelection prospects. Governing parties are trapped between being punished for economic mismanagement or for retrenching the welfare state (Green-Pedersen 2002). This also means that those governments who may not favor reform intrinsically have an incentive to pursue cutbacks if they expect that such reform may boost economic performance in the longer run.

To formalize the argument, we propose a tractable game that captures economic voting and the commitment problem that comes with it in a simple way. First, we discuss the players and their preferences (Sect. 3.1), along with the assumptions of the model (Sect. 3.2). Then,

\footnotetext{
${ }^{2}$ This mechanism differs from political-economic explanations that focus on the absence of reform. That literature typically assigns reform's absence to the 'nonneutrality' in the distribution of gains and losses in society. Reform is non-neutral because the winners from the status quo are assumed to be politically strong, while the losers are politically weak. Fernandez and Rodrik (1991) expand the argument, stating that it is the uncertainty about the distribution of gains and losses that impedes reform. If some of the winners and losers of the reform cannot be identified ex ante, the status quo is likely to prevail. In principle, reform and its absence are two sides from the same coin. However, a number of important theories accounting for the absence of reform fail adequately to explain its occurrence. Pierson's (2001) argument that political obstacles impede reform is one of them. Moreover, Fernandez and Rodrik's (1991) work helps to explain better the absence of reform than its presence, although the latter authors do specify a condition under which reform occurs (certainty over the distribution of gains and losses).
} 
we turn to the set-up of the model (Sect. 3.3) and present a special case that provides insight and intuition about how elections can discipline politicians (Sect. 3.4). Then, we discuss the most general version (Sects. 3.5 and 3.6) and, finally, an extension of the model (Sect. 3.7).

A game-theoretical model allows for formalizing the argument and thereby ensures its internal consistency. The model's logic may also lead to results not easily thought of otherwise. For example, in the model political parties may face a coordination problem between two equilibria (one reforming, the other not). This shows that postulating the voters' commitment problem does not just mechanically lead to presence of reforms during recessions but reveals a more subtle potential problem in the democratic process, namely that the logic of economic voting leads to the possibility of parties colluding or coordinating on reforms. It would subsequently be interesting to operationalize this collusion empirically or think about ways the democratic process could address this.

\subsection{The players and preferences}

Let us first discuss the preferences of the players in the game. There are three players: two politicians and one voter (the median one). Focusing on one voter only may seem too strict an assumption and one that does away too easily with voters' possible heterogeneous preferences regarding reform. Although we do not dismiss the fact the voters' preferences may very well vary, from the perspective of the governing party (or parties) the median voter's preferences are key. There is an extensive body of literature showing that mainstream parties that typically make up the government cater to precisely this median voter (e.g., Adams et al. 2006; Ezrow et al. 2011). If the median voter opposes reform of one or more welfare programs - either because it hurts her own consumption directly or because she sociotropically cares about the income of welfare programs' recipients-the reform entails an electoral risk for the governing party (or parties).

There is ample survey research showing that the median voter and favor the status quo to reform. Boeri et al. (2002), for example, find in a survey of the opinions on pension reform in Germany and Italy that most voters, including the median one, oppose welfare reforms and favor the state quo. Related, Van Groezen et al. (2009) find that a preference for the status quo induces voters, again including the median one, to be wary of pension reforms, even if these might improve their financial position in the longer term. Other scholars find similar preferences as well for welfare programs other than pensions (e.g., Blekesaune and Quadagno 2003; Brooks and Manza 2007). In general, reform typically means that the median voter incurs direct, (almost) immediate costs while the possible benefits are dispersed and often arise only in the long(er) run. Based on a survey experiment among American citizens, Jacobs and Matthews (2008) show that the uncertainty of a reform's long-run benefits is an important factor affecting whether citizens are willing to accept short-run pain (the reform) for longer-term gain (the reform's distant, positive consequences). Specifically, the less the government can be trusted to produce these longer-run positive effects, the more negative voters are about incurring short-run costs. In the context of welfare state reform that negatively affects the median voter in the short-run-the reforms we focus on here-this is an important point. There is always a real possibility that a proposed reform fails to lead to the expected outcomes. For instance, an increase in the age of pension eligibility may lead to more stable and lower public expenditures in the longer run, thereby positively affecting, for instance, the rate of economic growth. However, economic growth is influenced by many factors other than public spending alone, and most if not all of these factors are beyond the direct control of any government. In this example, while the rate of economic growth-and the consumption possibilities of voters - may have been even lower without raising the retirement age because the effect of the reform in the longer-run is not visible or the longer-run 
gain is small. Jacobs and Matthews (2008) also show that voters' cognitive capacity to reason inter-temporally is rather low. It is this cognitive limited capacity that underlies voters' attitude of such inter-temporal trade-offs. Therefore, we propose that voters will in general be unwilling to accept welfare state reforms that hurt them in the short-run and which yield only uncertain (and dispersed) longer-run benefits.

Against this backdrop, reforming one or more welfare programs is politically risky and something one would theoretically expect vote-seeking parties to steer away from. In our model, we set out to identify those conditions under which vote-seeking parties reform nonetheless. Our focus on two politicians, who can be seen as two political parties, means that our model applies directly to two-party systems such as the United States (US), Malta or-to a lesser extent - the United Kingdom (UK).

What are the players' utility functions? The two politicians both have a time-additive utility function, $V_{t}$, with a one-period utility function $U\left(x_{i}\right)$ that is concave and positive and where $x_{i}$ represents consumption at time $i$. The discount rate is $\beta$. The utility-function at time $t$ is given by:

$$
V_{t}=\sum_{i=t}^{\infty} \beta^{(i-t)} U\left(x_{i}\right)
$$

At each point in time, one and only one politician holds office. If a politician is out of office, she does not have any decision to make and utility is normalized to zero. If the politician is in office, she receives a positive endowment $w>0$.

The median voter also has a time-additive utility function with a well-behaved one period utility function, denoted $W(c)$. In each period the voter consumes $c_{\mathrm{g}}$ in good economic times and $c_{\mathrm{b}}$ in bad economic times with $c_{\mathrm{g}}>c_{\mathrm{b}}>0$. We assume, realistically as we argue above, that the median voter dislikes reform. The negative effect of a reform equals $\theta$ of consumption. This cost of reform is strictly positive. We think of this as the real costs of reform to the median voter (not necessarily all voters) like a less generous pension benefit. However, the costs can also be (re)interpreted (partly) as the psychological costs of any deviation from the status quo. Research on habit formation shows that many people prefer the status quo to change (the status quo bias).

The costs are positive but consumption in both economic circumstances remains positive, so $c_{\mathrm{g}}-\theta>c_{\mathrm{b}}-\theta>0$. Because the one-period utility function is increasing in consumption, it follows that $W\left(c_{\mathrm{g}}-\theta\right)>W\left(c_{\mathrm{b}}-\theta\right)$. The median voter's preferences are therefore such that under all circumstances she prefers no reform (the status quo) to reform. It is further necessary to assume that reforms are the only (salient) issue in elections.

\subsection{Assumptions of the model}

Our model hinges on three assumptions. The first one is that reforms are unpopular among the median voter. We have argued already that this is plausible. A second assumption is that economic motives dominate voting decisions. This does not mean that economic voting is equally strong in all democratic systems. In majoritarian systems, which typically have a one-party government, it is clear who to blame for the economic failure. The higher clarity of responsibility increases the likelihood that voters vote retrospectively (i.e., economically) compared to in systems with lower degrees of clarity (like parliamentary ones; see Powell and Whitten 1993 and Whitten and Palmer 1999). Since our game-theoretical model is closest to a majoritarian system with a one-party government, the lower relevance of economic voting in other electoral systems is not a problem. A final assumption is that governments 
Fig. 1 Timing of events

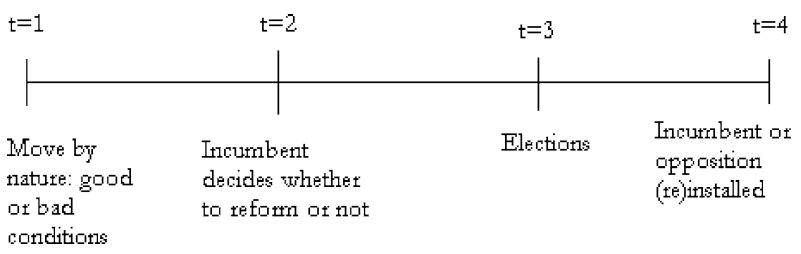

are primarily vote-seeking (Downs 1957), but that they can also be office-seeking or policyseeking. Herein we follow the behavioral literature on political parties (Strøm 1990; Müller and Strøm 1999). In our model, a government faces a trade-off between (1) remaining in office by catering to the wishes of the median voter, meaning that the government behaves as a vote-seeker, and (2) exclusion from office by adopting a policy that goes against the wishes of the median voter, indicating that the government acts more like a policy-seeker. When facing sure electoral defeat the policy-seeking motive dominates since winning office is no longer possible.

\subsection{The stage-game}

For both the politician in office and the median voter, the following game unfolds in three stages:

1. There is a move by nature that determines the economy's performance. With probability $\lambda$ the economic circumstances are good; with probability $1-\lambda$ they are bad.

2. Next, the politician in office can choose between two actions. The first is to reform; the second is to stick to the status quo (i.e., no reform). In the former case, the politician receives, in addition to $w$, a positive amount $r>0$. This may be interpreted as her personal benefits from reforming, for instance in the form of ideological satisfaction.

3. After observing the state of the economy and the action of the politician, the median voter has the option to either re-elect the politician or not. If the politician is not re-elected, the other politician is elected automatically. Figure 1 depicts the sequence of moves in the three-stage game where the (re)installment of the new government at $t=4$ ends it.

The politicians' action space consists of two choices: reform or no reform. The median voter's action space also consists of two actions: re-election or no re-election. We restrict the strategies and the equilibria of the players in several ways. First, we consider only pure strategies. Second, we restrict attention to Markov equilibria. In Markov equilibria, players' actions are a function of the current, payoff- relevant state. We define the economy's state as good or bad, ruling out the possibility that the players condition their actions on the entire economic history or the history of others players' actions. Third, as we assume the two politicians to be identical; we consider only symmetric equilibria where both politicians adopt the same strategy. ${ }^{3}$

For the politician, a strategy maps the state of the economy into the action reform or no reform. A strategy thus consists of a pair that prescribes the action when the economy is in a bad and in a good state, respectively. The voter has a strategy that maps the economy's performance and the action of the politician into the action re-election or no re-election. The

\footnotetext{
${ }^{3}$ The assumption of identical politicians does not imply that the political parties have identical preferences on all other issues. It means only that both parties take the preference of the median voter into account in their decision concerning welfare program reforms. As we elaborate in the main text, this is a plausible assumption.
} 
voter's strategy therefore has to prescribe an action in four circumstances, conditional on the state of the economy (either good or bad) and on the action of the politician (reform or no reform).

\subsection{Equilibria with perfect conditioning}

First, we consider the situation where the voter can condition re-election perfectly on the occurrence of reform. This is a special case of the general model we present later. Economic circumstances are not relevant in this first model, which means that the voter's optimal strategy is to reelect a politician who does not reform and does not re-elect a politician who does. Subsequently, there are two potential pure strategy equilibria; one with both politicians always reforming and one with both politicians never reforming.

The equilibrium with both politicians always reforming occurs if the following condition (1) holds: ${ }^{4}$

$$
U(w+r)-U(w)>\frac{\beta}{1-\beta} U(w)-\frac{\beta^{2}}{1-\beta^{2}} U(w+r)
$$

The left-hand side gives the immediate gain from reforming compared to not reforming. The right-hand side gives the difference of the remaining lifetime utility of never reforming and the lifetime utility of always reforming (given that the other politician always reforms). In the latter case, both politicians are in office every second period and reform when they are. Under condition (1), given that the other politician always reforms, it is best to do likewise. As the two politicians are similar, this constitutes a Nash-equilibrium. Note that if $\beta=0$, the condition is always met, as $r>0$. In that case, future income is not considered at all and reforming is more attractive.

Another possible equilibrium is one with both politicians not reforming. A necessary condition for such an equilibrium is:

$$
U(w+r)-U(w)<\frac{\beta}{1-\beta} U(w)
$$

Note that if $\beta=0$, the condition is never met. This condition states that, given that the other politician never reforms, never reforming and hence holding office forever after leads to higher life-time utility than reforming once and never being (re)elected again.

Summarizing, there are three possibilities.

1. $U(w+r)-U(w)$ is small, condition (2) is met and condition (1) is not met. This means that the lifetime utility of always holding office is large. Reforming is not attractive, even if the other politician does likewise. The equilibrium with both politicians never reforming occurs.

2. $U(w+r)-U(w)$ is large, condition (1) is met and condition (2) is not. The utility of even a one-time reform is large and there will always be reform. In that case, there is no way for the voter to discipline the politician by not reelecting her.

3. $U(w+r)-U(w)$ has an intermediate value and conditions (1) and (2) are both met. In this case both equilibria are possible. Which one occurs, depends on the ability of the two politicians to coordinate on the equilibrium of both of them reforming. This latter equilibrium provides both politicians with a higher lifetime utility than the equilibrium where both never reform.

\footnotetext{
${ }^{4}$ Here and in the remainder of the article, we use the familiar convergence result of a geometric series.
} 
This third case is arguably the most interesting one, because it results in a coordination problem where both politicians can agree on an action that benefits them but that is not in the median voter's interest. As indicated, such a situation is perfectly reconcilable with a democratic process and vote-seeking parties because of voters' commitment problem. The outcome is then that both parties constantly pursue reforms the median voter dislikes. If politicians indeed coordinate successfully, a further strategy of the voter could be to never re-elect one of the two politicians once she reformed and to always re-elect the other one, irrespective of that politician reforming or not. With such a voter's strategy, the politician aims for the strategy of no reform.

Note that it is impossible for both conditions not to be met, since the right-hand side of condition (2) is larger than the right-hand side of condition (1).

\subsection{Equilibria with economic voting}

We now turn to the model's more general and more realistic version wherein the voter can only condition re-election imperfectly on the action of the politician in office. As an extreme case of economic voting, the politician is never re-elected when the economy is slowing down, irrespective of whether she reformed. This constitutes the commitment problem of the voter who cannot credibly commit to re-elect a government that does not reform. Consequently, the politician will always reform during a recession. For the politician, reforming does not alter the prospects of being re-elected while there is a positive pay-off $r>0$. During booms, a politician is still never re-elected after a reform, as before.

Again, two equilibria are possible. The web appendix (available at www.barbaravis.nl) shows the following necessary condition (3) for an equilibrium where both politicians will not reform in good times; this is the analogy of condition (2):

$$
\begin{aligned}
U(w+r)-U(w)< & \frac{\beta(1-\lambda \beta[\lambda U(w)+(1-\lambda) U(w+r)]}{1-2 \beta \lambda-\beta^{2}+2 \beta^{2} \lambda} \\
& -\frac{\beta^{2}(1-\lambda) U(w+r)}{1-\beta \lambda-(1-\lambda) \beta^{2}}
\end{aligned}
$$

Note that condition (3) reduces to condition (2) if $\lambda=1$. In this particular case, economic circumstances are always positive and the voter can perfectly condition re-election on the actions of the politicians. Note also that if $\beta=0$, the condition never holds; in that case either politician takes the future into account and they will therefore always reform.

For the equilibrium with both politicians reforming the necessary condition reads:

$$
\begin{aligned}
U(w+r)-U(w)> & \frac{\beta}{1-\beta \lambda-(1-\lambda) \beta^{2}}[\lambda U(w)+(1-\lambda) U(w+r)] \\
& -\frac{\beta^{2}}{1-\beta^{2}} U(w+r)
\end{aligned}
$$

Note that, as before, condition (4) reduces to condition (1) if $\lambda=1$. Note also that if $\beta=0$, the condition always holds.

In the web appendix, we show that the right-hand side of condition (3) is larger than the right-hand side of condition (4). Therefore it is not possible for both conditions not to be met and there is always at least one equilibrium. Generally, there are again three possibilities. A unique equilibrium with both politicians always reforming; a unique equilibrium with both never reforming during booms; and the possibility that there are two equilibria. Which 
Table 1 Comparative statics

\begin{tabular}{lll}
\hline Parameter & Condition (3) & Condition (4) \\
\hline$w$ & + & - \\
$r$ & - & + \\
$\lambda$ & $+/-$ & $+/-$ \\
$\beta$ & $+/-$ & $+/-$ \\
\hline
\end{tabular}

one occurs in the latter case depends on which equilibrium the two politicians coordinate. ${ }^{5}$ The equilibrium where both reform has higher lifetime utility than the one where neither reforms. This follows from the observation that condition (3) is met and it is then better not to reform than to reform, given that the other politician does not reform. Condition (4) is also met, implying that it is better to reform than not to reform, given that the other politician reforms. It holds that not reforming when the other reforms yields greater lifetime utility than not reforming when the other does not reform. In both cases, the politician has the same income when in office and is only out of office after bad economic times. However, in the latter case the probability of coming back into office is smaller, because the other politician does not reform during booms. Combining these observations, we find that in the case of multiple equilibria, the two politicians have higher lifetime utility in the equilibrium of both reforming than of both not reforming. For the voter the opposite holds; the equilibrium with both politicians not reforming increases her utility.

\subsection{Comparative statics}

We investigate the comparative statics to assess how the four different parameters in the model influence the willingness to reform and the median voter's ability to discipline the politicians (see Table 1).

It can be shown that, ceteris paribus and for all $w$, condition (3) will more likely be met when the endowment $w$ increases, i.e., the right-hand side increases more than the lefthand side. If the endowment increases, reform is less likely to occur. This follows because reform leads to the loss of the endowment $w$ in the next period and possibly in subsequent periods. The larger is this loss, the less likely a politician reforms. This implies that an increase in politicians' income-the endowment $w$-decreases the probability of reforms during prosperous economic times. The opposite holds for condition (4): the higher is $w$, the less likely the condition is met and the less likely is an equilibrium with both politicians reforming.

Furthermore, ceteris paribus and for all $r$, condition (3) will less likely be met when the personal satisfaction from reform $(r)$ increases; then the right-hand side then decreases more than the left-hand side. The higher is $r$, the more likely reform is. This formalizes the idea that a larger personal satisfaction from reform make undertaking reform more attractive. The opposite holds for condition (4); the higher is $r$, the more likely the condition is met and the more likely is an equilibrium with both reforming.

\footnotetext{
${ }^{5}$ This constitutes a classical $2 \times 2$ coordination game with two players (the two politicians) and two pure strategies (either always reform or never reform during economic prosperity); see Mas-Colell et al. (1995). The two pure strategy equilibria are that both players choose to always reform or that both players choose not to reform. The first equilibrium Pareto dominates the latter, so when possible (for example with pre-play communication), the players would coordinate on the equilibrium to always reform.
} 
For both conditions, the comparative statics of $\lambda$ and $\beta$ are not straightforward. The partial derivative of the bound can be both positive and negative. This means that a larger probability of economic hardship and a higher discount rate do not have an unambiguous effect. Consider, for example, the equilibrium at which both politicians reform during good economic times (and are voted out of office because of that). A higher subjective discount rate increases the value of remaining in office as the expected future gains that come with it increase. However, it also increases the discounted values of future reforms during good times. These counteracting effects depend on the discount factor $\beta$ in a non-linear way. Neither of the effects dominates and thus the net effect can go either way. The sign depends on the particular values of the parameters and the functional form of the utility function, making general predictions of the effect impossible.

\subsection{A positive effect of reform on economic conditions}

The basic model postulates that reforms do not affect the economy except for a positive endowment for the reforming politician-interpreted as the politician's personal satisfaction from reform $(r)$ - and a one-time negative impact on the median voter. While this is enough to capture the mechanism we focus on (the voter's commitment problem), it does away with the possibility that reforms eventually will increase (or decrease) welfare. One could, for example, argue that pension reforms, although lowering the utility of the median voter, may have a positive impact on the welfare of future generations (see e.g., Browing 1975).

To incorporate such effects fully, the probability of the economy being in a good state should be dependent on all previous reforms. This can be handled in numerous and complicated (non-linear) ways. This section considers the simplest version in which one and only one reform leads to a one-time increase in the probability that the economy is in a good state from $\lambda$ to $\lambda^{*}$, with $\lambda^{*}>\lambda$. First, we consider the median voter's preferences and actions; then we turn to the politicians' strategies.

Thus far, the interpretation of the median voter was immaterial to the model's outcomes. When current actions affect future periods, the interpretation becomes important. Two interpretations of the median voter are possible: (1) each period there is a different median voter or (2) there is a long-lived player. If the median voter differs each period, and current young or unborn voters are the future's median voter, it is clear that at some point future voters want a reform that results in $\lambda^{*}$ while the current median voter might not want a reform. In these cases, reform benefits future (median) voters and current politicians, but not the current median voter.

If, however, the median voter is interpreted as a long-lived player, she might also prefer a one-time reform (and none thereafter) during economic prosperity to no reform at all if the following condition is met:

$$
\begin{gathered}
W\left(c_{\mathrm{g}}-\theta\right)+\frac{\beta}{1-\beta}\left[\lambda^{*} W\left(c_{\mathrm{g}}\right)+\left(1-\lambda^{*}\right) W\left(c_{\mathrm{b}}\right)\right] \\
>W\left(c_{\mathrm{g}}\right)+\frac{\beta}{1-\beta}\left[\lambda W\left(c_{\mathrm{g}}\right)+(1-\lambda) W\left(c_{\mathrm{b}}\right)\right]
\end{gathered}
$$

For this median voter there is a trade-off between the immediate negative impact, captured by $\theta$, and the future benefit of the reform, indicated by $\lambda^{*}>\lambda$. However, beyond the first reform the median voter does not want any further reforms due to the assumption that only a one-time increase in $\lambda$ is possible.

A politician facing a reform decision now not only faces the reform's current gain $(r)$, but also the long-term impact given by $\lambda^{*}$. For now assuming that the median voter does not 
reelect a reforming government, the increase of $\lambda$ is not to the politician's advantage because it lowers the probability of being in office any time soon. In the extreme case when $\lambda^{*}=1$, the politician may never be in office again. The paradoxical situation may then result that both politicians never reform (i.e., neither in bad and good economic times) if the following condition holds:

$$
\begin{aligned}
& U(w)\left[1+\beta \frac{(1-\lambda) \beta}{\left(1-2 \beta \lambda-\beta^{2}+2 \lambda \beta^{2}\right)}\right] \\
& >U(w+r)+\beta \frac{\left(1-\lambda^{*}\right) \beta\left[\lambda^{*} U(w)+\left(1-\lambda^{*}\right) U(w+r)\right]}{\left(1-2 \beta \lambda^{*}-\beta^{2}+2 \lambda^{*} \beta^{2}\right)}
\end{aligned}
$$

Expression (6) is derived under the assumption that the equilibrium with neither politician reforming results after one reform (see the web appendix for the details). The model's extension thus leads to a new equilibrium with both politicians never reforming, hereby expanding the types of equilibria that can be rationalized. It is thus possible that future median voters do want a one-time reform but this never happens because the reforming politician thereby not only increases the probability that the economy prospers but also that the other politician remains in office.

As indicated above, the median voter when interpreted as a long-lived player may however desire a reform if condition (5) is met. In that case the median voter may consider re-electing a politician that reforms during an economic upswing (during busts the commitment problem hinders this still) if this is the first reform. After any subsequent reform, the median voter does not re-elect the reforming politician. This strategy will induce a politician to reform because she now receives both the personal satisfaction from reforming and remains in office. However, this will also trigger multiple reforms later on when times are bad, which the median voter dislikes. The median voter will reward the first reform nonetheless if the increase in $\lambda$ is large enough. Formally, the following condition (7) is necessary for the median voter to re-elect the first politician who reforms during a boom:

$$
\begin{gathered}
W\left(c_{\mathrm{g}}-\theta\right)+\frac{\beta}{1-\beta}\left[\lambda^{*} W\left(c_{\mathrm{g}}\right)+\left(1-\lambda^{*}\right) W\left(c_{\mathrm{b}}-\theta\right)\right] \\
>W\left(c_{\mathrm{g}}\right)+\frac{\beta}{1-\beta}\left[\lambda W\left(c_{\mathrm{g}}\right)+(1-\lambda) W\left(c_{\mathrm{b}}\right)\right]
\end{gathered}
$$

Expression (7) is derived under the assumption that the equilibrium with both not reforming results after one reform. If, however, the equilibrium with both parties always reforming results the condition becomes harder to fulfill as then the utility during good economic times equals $W\left(c_{\mathrm{g}}-\theta\right)$ after a reform. Condition (7) describes the situation that voters prefer; for example, a one-time reform to the pension system but reject incremental cut-backs.

As said, a more complicated relation between the number of reforms and the probability $\lambda$ is both possible and reasonable. The model can likewise be extended in several other ways. More than two politicians could be considered, more policy issues or changing voter preferences could be taken into account. This would strengthen the assumptions' plausibility and thereby the results' validity. However, it would also make the model more complex, making analytical solutions intractable if not non-existent.

\section{Discussion and conclusion}

Under what circumstances do vote-seeking governments pursue welfare program reforms that are unpopular with the median voter and therefore likely lead to electoral punishment? 
Existing work in comparative welfare state research and the political economy of reforms offer some helpful starting points, but do not provide a convincing answer to this question. In this article, we presented a simple game-theoretical model to identify when politicians pursue unpopular reforms and when they do not. We have shown that parties that primarily seek votes can still opt to reform welfare programs, even though the median voter prefers the status-quo. In the model, we stack the cards against reform by assuming that parties are primarily vote-seeking and that the median voter opposes reform. Our model shows that even in this reform-hostile setting, reform is possible. The most interesting outcome is that for a relevant range of parameters the politicians face a coordination problem. Both politicians in the model prefer to coordinate on an equilibrium where they both always reform. The median voter is then worse off, but she cannot prevent reform because of the commitment problem related to retrospective economic voting. An extension of the model allows the first reform to increase the probability of future prosperity. It is then possible that the current median voter favors reform. In that case, the median voter may support an initial reform that increases future welfare but will oppose all subsequent reforms.

The result of our model helps to shed light on a theoretical puzzle in the literature on unpopular reforms. Our model's empirical implication is that policy reforms are initiated during recessions, which is in line with the findings of, for example, Høj et al. (2006). Our contribution lies in presenting the underlying theoretical mechanism at work: the occurrence and timing of reforms spring from an intrinsic voter commitment problem.

The model's empirical implication, reform occurring during economic downturns, also identifies the condition under which an 'objective' socio-economic problem matters: socioeconomic dire straits. Assuming that voting is driven by economic performance, it is likely that the incumbent party or parties will not be re-elected during times of recession, irrespective of their particular policy. Economic setbacks thus allow a government to act against the wishes of the median voter, because the government knows it is almost surely headed for electoral defeat regardless of its actions. Our findings also contribute to the literature that examines the impact of ideas on reform by indicating that a poor socio-economic state enables politicians to act based on their own ideas or interests. With respect to studies focusing on partisanship, our model shows that the government's color is irrelevant, as both leftist and rightist politicians face a median voter who opposes welfare program reform. The empirical work of, for instance, Vis (2010) corroborates this prediction.

Our model with two politicians and one voter (the median one) is appropriate for advanced democracies with a two-party system and a majority, plurality or one-party government. The number of such countries is limited as most have more than two parties (although a single-party government will still typically emerge when there are relatively few parties). In future work, it would be interesting to expand the number of parties included in the model.

Acknowledgements Many thanks to the participants of the Politicologenetmaal 2009, Lex Meijdam, Gijs Schumacher and Nick Vikander for their helpful comments on an earlier version of this article. We also thank the anonymous reviewers of Public Choice and the editors for their constructive comments. Barbara Vis' research was supported by a Veni grant from the Netherlands Organisation for Scientific Research (NWO, grant No. 451-08-012).

Open Access This article is distributed under the terms of the Creative Commons Attribution Noncommercial License which permits any noncommercial use, distribution, and reproduction in any medium, provided the original author(s) and source are credited.

\section{References}

Acemoglu, D. (2003). Why not a political Coase theorem? Social conflict, commitment, and politics. Journal of Comparative Economics, 31(4), 620-652. 
Adams, J., Clark, M., Ezrow, L., \& Glasgow, G. (2006). Are niche parties fundamentally different from mainstream parties? The causes and the electoral consequences of Western European parties' policy shifts, 1976-1998. American Journal of Political Science, 50(3), 513-529.

Allan, J. P., \& Scruggs, L. A. (2004). Political partisanship and welfare state reform in advanced industrial democracies. American Journal of Political Science, 48(3), 496-512.

Armingeon, K., Engler, S., Potolidis, P., Gerber, M., \& Leimgruber, P. (2010). Comparative Political Data Set 1960-2008. Institute of Political Science, University of Berne. http://www.ipw.unibe.ch/content/team/ klaus_armingeon/comparative_political_data_sets/index_ger.html.

Barro, R. J. (1979). On the determination of the public debt. Journal of Political Economy, 87(5), 940-971.

Becker, G. S. (1983). A theory of competition among pressure groups for political influence. Quarterly Journal of Economics, 98(3), 371-400.

Besley, T. J., \& Coate, S. (1997). An economic model of representative democracy. Quarterly Journal of Economics, 108(1), 85-114.

Blekesaune, M., \& Quadagno, J. (2003). Public attitudes toward welfare state policies: a comparative analysis of 24 nations. European Sociological Review, 19(5), 415-427.

Boeri, T., Boersch-Supan, A., \& Tabellini, G. (2002). Pension reforms and the opinions of European Citizens. American Economic Review, 92(2), 396-401.

Bonoli, G. (2001). Political institutions, veto points, and the process of welfare state adaptation. In P. Pierson (Ed.), The new politics of the welfare state (pp. 238-264). Oxford: Oxford University Press.

Breyer, F., \& Craig, B. (1997). Voting on social security: evidence from OECD countries. European Journal of Political Economy, 13(4), 705-724.

Brooks, C., \& Manza, J. (2007). Why welfare states persist: the importance of public opinion in democracies. Chicago: University of Chicago Press.

Browning, E. K. (1975). Why the social insurance budget is too large in a democracy. Economic Inquiry, 13(3), 373-388.

Campbell, J. L. (2002). Ideas, politics, and public policy. Annual Review of Sociology, 28, 21-38.

Congleton, R. D., \& Bose, F. (2010). The rise of the modern welfare state, ideology, institutions and income security: analysis and evidence. Public Choice, 144(3-4), 535-555.

Congleton, R. D., \& Shughart, W. F. (1990). The growth of social security: electoral demand or political pull? Economic Inquiry, 28, 109-132.

Congleton, R. D., Batinti, A., Bose, F., Kim, Y., \& Pietrantonio, R. (2011, forthcoming). Public choice and the modern welfare state, on the growth of government in the twentieth century. In W. F. Shughart, L. Razzolini, \& M. Reksulak (Eds.), Elgar companion to public choice. Cheltenham: Edward Elgar.

Cox, R. H. (2001). The social construction of an imperative: why welfare state reform happened in Denmark and the Netherlands but not in Germany. World Politics, 53(3), 463-498.

Downs, A. (1957). An economic theory of democracy. New York: Harper and Row.

Easaw, J. (2010). It's all 'bad' news! Voters' perception of macroeconomic policy competence. Public Choice, 145(1), 253-264.

Ezrow, L., De Vries, C. E., Steenbergen, M., \& Edwards, E. E. (2011). Mean voter representation versus partisan constituency representation: do parties respond to the mean voter position or to their supporters? Party Politics, 17(3), 175-301.

Fernandez, R., \& Rodrik, D. (1991). Resistance to reform: status quo bias in the presence of individualspecific uncertainty. American Economic Review, 81(5), 1146-1155.

Galasso, V., \& Profeta, P. (2002). The political economy of social security: a survey. European Journal of Political Economy, 18(1), 1-29.

Garrett, G., \& Mitchell, D. (2001). Globalization, government spending and taxation in the OECD. European Journal of Political Research, 39(2), 145-177.

Green-Pedersen, C. (2002). The politics of justification: party competition and welfare-state retrenchment in Denmark and the Netherlands from 1982 to 1998. Amsterdam: Amsterdam University Press.

Grossman, G. M., \& Helpman, E. (1996). Electoral competition and special interest politics. Review of Economic Studies, 63(2), 265-286.

Hibbs, D. A., Jr. (1979). The mass public and macroeconomic performance: the dynamics of public opinion toward unemployment and inflation. American Journal of Political Science, 23(4), 705-731.

Høj, J., Galasso, V., Nicoletti, G., \& Dang, T. (2006). The political economy of structural reform: empirical evidence from OECD countries (Working Papers, No 501). OECD Economics Department.

Huber, E., \& Stephens, J. D. (2001). Development and crisis of the welfare state: parties and policies in global markets. Chicago: The University of Chicago Press.

Iversen, T. (2005). Capitalism, democracy, and welfare. Cambridge: Cambridge University Press.

Jacobs, A. M., \& Matthews, J. S. (2008). Does timing matter? Intertemporal policy choice and the mass public. Paper prepared for the Annual Meeting of the Midwest Political Science Association, April 3-6, Chicago. 
Kitschelt, H. (2001). Partisan competition and welfare state retrenchment: when do politicians choose unpopular policies. In P. Pierson (Ed.), The new politics of the welfare state (pp. 265-302). Oxford: Oxford University Press.

Korpi, W., \& Palme, J. (2003). New politics and class politics in the context of austerity and globalization: welfare state regress in 18 countries, 1975-1995. American Political Science Review, 97(3), 425-446.

Lewis-Beck, M. S., \& Paldam, M. (2000). Economic voting: an introduction. Electoral Studies, 19(2), 113121.

Lieberman, R. C. (2002). Ideas, institutions, and political order: explaining political change. American Political Science Review, 96(4), 697-712.

Mas-Colell, A., Whinston, M. D., \& Green, J. R. (1995). Microeconomic theory. Oxford: Oxford University Press.

Meltzer, A. H., \& Richard, S. F. (1981). A rational theory of the size of government. The Journal of Political Economy, 89(5), 914-927.

Müller, W. C., \& Strøm, K. (1999). Policy, office or votes: how political parties in Europe make hard decisions. Cambridge: Cambridge University Press.

Mulligan, C. B., Gil, R., \& Sala-i-Martin, X. (2002). Social security and democracy. The B.E. Journal of Economic Analysis \& Policy, 10(1), Article 18.

Niskanen, W. A. (1971). Bureaucracy in representative government. Chicago: Aldine Atherton.

Olson, M. (1965). The logic of collective action. Cambridge: Harvard University Press.

Pacek, A., \& Radcliff, B. (1995). Economic voting and the welfare state: a cross-national analysis. Journal of Politics, 57(1), 44-61.

Persson, T., \& Tabellini, R. G. (2000). Comparative politics and public finance. Journal of Political Economy, 108(6), 1121-1161.

Pierson, P. (2001). Post-industrial pressures on mature welfare states. In P. Pierson (Ed.), The new politics of the welfare state (pp. 80-104). Oxford: Oxford University Press.

Pitlik, H., \& Wirth, S. (2003). Do crises promote the extent of economic liberalization? An empirical test. European Journal of Political Economy, 19(3), 565-581.

Powell, G. B., \& Whitten, G. D. (1993). A cross-national analysis of economic voting: taking account of the political context. American Journal of Political Science, 37(2), 391-414.

Ross, F. (1997). Cutting public expenditures in advanced industrial democracies: the importance of avoiding blame. Governance: An International Journal of Policy and Administration, 10(2), 175-200.

Schmidt, V. A. (2002). Does discourse matter in the politics of welfare state adjustment? Comparative Political Studies, 35(2), 168-193.

Sjoblom, K. (1985). Voting for social security. Public Choice, 45(3), 225-240.

Starke, P. (2006). The politics of welfare state retrenchment: a literature review. Social Policy \& Administration, 40(1), 104-120.

Strøm, K. (1990). A behavioral theory of competitive political parties. American Journal of Political Science, 34(2), 565-598.

Tabellini, G. (2000). A positive theory of social security. Scandinavian Journal of Economics, 102(3), 523545.

Tepe, M., \& Vanhuysse, P. (2009). Are aging OECD welfare states on the path to the politics of gerontocracy? Evidence from 18 democracies. 1980-2002. Journal of Public Policy, 29(1), 1-28.

Tufte, E. R. (1978). Political control of the economy. Princeton and New York: Princeton University Press.

Van der Brug, W., Van der Eijck, C., \& Franklin, M. (2007). The economy and the vote: economic conditions and elections in fifteen countries. New York: Cambridge University Press.

Van Groezen, B., Kiiver, H., \& Unger, B. (2009). Explaining Europeans' preferences for pension provision. European Journal of Political Economy, 25(2), 237-246.

Vis, B. (2009). Governments and unpopular social policy reform: biting the bullet or steering clear? European Journal of Political Research, 48(1), 31-57.

Vis, B. (2010). Politics of risk-taking: welfare state reform in advanced democracies. Amsterdam: Amsterdam University Press.

Vis, B., \& Van Kersbergen, K. (2007). Why and how do political actors pursue risky reforms? Journal of Theoretical Politics, 19(2), 153-172.

Weaver, R. K. (1986). The politics of blame avoidance. Journal of Public Policy, 6(4), 371-398.

Whitten, G. D., \& Palmer, H. D. (1999). Cross-national analyses of economic voting. Electoral Studies, 18(1), 49-67. 